\title{
SELF-ORGANISATION INITIATIVES IN COMMUNITY-BASED CONSERVATION: A CASE STUDY OF BUNG JAGOI HERTIAGE BAU, SARAWAK MALAYSIA
}

\author{
AHI SAROK \\ Faculty of Social Sciences, Universiti Malaysia, Sarawak \\ FREDICIA BEATRICE BRITIN \\ Faculty of Social Sciences, Universiti Malaysia, Sarawak
}

*Corresponding author

sahi@unimas.my

\begin{abstract}
This article examines the small-scaled, village-based, self-organised initiatives community-based conservation $(C B C)$ of Bung Jagoi Heritage, Bau, Sarawak. The community self-organisation criteria are adopted in this study. The initiatives are developed through the CBC Projects under the Equator Initiative (EI) of the United Nation Development Programme (UNDP) which are considered successful by the EI. This article also investigates the impact of Bidayuh customary law or adat on the access and forest resources management in the communal forest of Bung Jagoi Heritage which utilised the Adat Bidayuh Order, 1994 and native customs as their guidelines for managing the access and forest resources. The level of participation among the villagers and the committee members is also assessed in this study based on the widely used participation typology developed by Jules N. Pretty. The data for this study is gathered through semi-structured interviews (SSIs) and observation. The findings of this study shows that the self-organisation in $C B C$ of Bung Jagoi Heritage is initiated by a small number of Jagoi-Duyoh villagers due to some outsiders' mysterious visits and concerns to conserve the forested land that also situate an ancestral village and its biodiversity as well as to develop the Bung Jagoi Heritage through the conservation activities. The success of this $C B C$ self-organisation relies heavily on the involvement and commitment of the committee members, funding from the local and international donors, and leadership of the committee's advisor in order for it to sustain and develop. The local community practices collectively known as the adat gives some impact on the access and forest resources through its communal tenure and traditional beliefs. The level of participation among the villagers can be categorised as 'participation for material incentive' while the level of participation among the committee member can be categorised as 'self-mobilisation'.
\end{abstract}

Key words: self-organisation, community-based conservation (CBC), customary law, adat, forest resources, participation, Bidayuh, Jagoi. 


\section{INTRODUCTION}

The article is written based on a study undertaken at Jagoi area, the Bidayuh-Jagoi or BiJagoi (henceforth BiJagoi) ancestral village which is located on Bung Jagoi in Bau district, Kuching. Bau district is in the Kuching division, Sarawak. Bau district has an area of approximately 884.4 square kilometres and shares the same borders with West Kalimantan, Indonesia. It is located approximately 35 kilometres Southwest of Kuching (Bau District Office, 2015). The BiJagoi group were originally from Mount Bratak; an old settlement where the Bidayuhs who first migrated from Sungkung in Western Kalimantan, Indonesia and settled down there. The BiJagoi moved from Mount Bratak to Mount Jagoi sometime in early 1838 to avoid attacks from the enemies (Chang, 2000, p. 8). Hence, Bung Jagoi was the first Bidayuh settlement within Jagoi area. Around the 1920s, the BiJagoi moved down from Bung Jagoi due to the growing number of population, scarcity of land for agriculture and housing, and scarcity of water during drought season on the top of the mountain (Chang, 2002, p. 92). Also, the BiJagoi sensed that they were unable to farm around Bung Jagoi especially paddy because the activities of slash and burn will be destroying the forest and lead to decrements of flora and fauna. The BiJagoi prefer to live in the lowland areas because it is more convenient for them to travel from one place to another. Based on the historical facts, evidently some of the land at Bung Jagoi belongs to the descendant of the person who first cleared the area. The BiJagoi used to live at the ancestral village before they moved down to their present settlements (village) located at Bogag, Jagoi-Duyoh, Jagoi-Gunong, Jagoi-Pinomu, Jagoi-Sri'ieng, Sebobok, Serasot, Serikin, Skibang, and Stass

The year 2002 witnessed the establishment of a self-organisation CBC. It was initiated as a result of local communities' interests and motivation to protect and preserve their 'ancestral property' of biodiversity and forest in Bung Jagoi for the benefit of the current and future generation. By protecting and preserving the biodiversity and forest, the local communities gained control over the natural resources. In addition the $\mathrm{CBC}$ also aims to develop the Bung Jagoi through the conservation activities. It was initiated by a small number of local communities who were mostly from the Jagoi-Duyoh village. In the year 2007, an informal self-organised CBO was established namely Jagoi Area Development Committee (JADC) to managed the Bung Jagoi. Since then, Bung Jagoi recognised as Bung Jagoi Heritage. The JADC represented by local communities from the Jagoi area with various background and interest. One of the JADC's committee members become the committee member of JOAS representing the State of Sarawak (the member of JADC, personal communication, December 25, 2015).

The conservation area in Bung Jagoi Heritage involves the ancestral village site and the forested land with an area of more than 400 hectares which encompasses biodiversity in the primary and secondary forest. These have been declared as pulau tu'aan (communal forest) by the JADC with consent granted by the land owners. In order to conserve and manage the commonpool resources (natural resources) in Bung Jagoi Heritage, the JADC utilised the adat of Native Customary Laws Ordinance and native customs which is orally being passed down from their ancestors as their guidelines

Efforts made by JADC's participants between the year 2008 and 2009, enabled this informal CBO to obtain fund from the Rainforest Foundation Norway (RFN) and Danish International Development Agency (DANIDA). RFN is an organisation that supports indigenous 
peoples and traditional populations of the Amazon, Central Africa, Southeast Asia and Oceania in their efforts to protect their environment and fulfil their rights (Rainforest Foundation Norway, n.d.). The Bung Jagoi Heritage CBC project was also funded by Shell Malaysia, the GEF of UNDP under the Small Grants Programme (SGP) in Malaysia, Ministry of Tourism and Heritage Sarawak, State and Federal Representatives, Sarawak Biodiversity Centre (SBC), local leaders and committee members of this CBC initiative.

Some of the CBC activities executed by the local communities together with the committee members in Bung Jagoi Heritage include the setting up of a herbal garden. Their missions are; to make the area as a centre of herbaceous plant, to maintain the landscape by replanting plants that are able to be commercialised, to maintain the BiJagoi culture, to determine, record, and collect all the plants that has its usages in the daily life, to record and keep valuable plants and to maintain the Bidayuh's traditional knowledge in order to be inherit by the younger generations. The documentation of natural resources had been done by the communities together with the local institution such as Universiti Malaysia Sarawak (UNIMAS) and SBC to preserve and protect the historical, cultural, and biodiversity values. The herbal garden encompasses more than thirty species of medicinal, spice, and food plant (Sayok, Noweg, and Pahon, 2014, p. 39).

\section{APPROACHES IN COMMUNITY-BASED CONSERVATION}

$\mathrm{CBC}$ has two approaches and self-organisation is one of the methods in managing the CBC initiatives. The CBC's first approach is to integrate the goals of conservation and development while the second approach depends on the customary arrangements to obtain consent from involved parties (Berkes and Seixas, 2004, p. 3; Ruiz-mallén, Schunko, Corbera, Rös, and Reyesgarcía, 2015). The two approaches empower local communities or indigenous people to actively participate and incorporate their knowledge and interests into the development of a biodiversity conservation project (Souto, Deichmann, Núñez, and Alonso, 2014, p. 1332; Campbell and Vainio-Mattila, 2003). Self-organisation is also a village-based and small-scale project that is fully administered and monitored by the local communities which hold the power, roles, and responsibility over the local natural resources are in their hand (Shukla and Sinclair, 2010).

CBC is articulated as a complex system by Levin (1999, p.12). According to Berkes and Davidson-Hunt (2007, p. 213; Agrawal and Gibson 2001, p.1), CBC is a complex system because it involves communities or competing groups with different interests, status, religion, political and economic power, ethnic group, as well as differentiation by gender and age. Communities may or may not share the same space and may range from a few individuals to hundreds or even thousands of people. Regardless of the complexity, self-organisation has been recognised by the Equator Initiative (EI) of UNDP as key towards the victory of CBC (Shukla et al., 2010, p. 205).

According to Seixas and Davy (2008, p. 99), the success of self-organisation in CBC is achieved if the organisation has mix of at least six fractions of the self-organisation criteria in the project initiatives such as (1) involvement and commitment of key players (including communities), (2) funding, (3) strong leadership, (4) capacity building, (5) partnership with supportive organisations and government, and (6) economic incentives (including alternative livelihood options). 
$\mathrm{CBC}$ also involves the participation of local communities which is fundamental in the conservation initiatives because it is able to influence the development strategies and interventions (Mikkelsen, 2005, p. 53). This is to ensure the success of the initiatives as the role of local participation is important in rural development programmes especially in conservation programme (Little, 1994, p. 347) because the lack of local participation will contribute to the failures of development (Khwaja, 2004, p. 427). The process entails the building of genuine partnerships between local communities and national institutions or non-governmental organisations (NGOs) implementing projects in the locality. Based on the populist approach of natural resources conservation and development, it stresses on the empowerment and participation of the local community as a key to sustainable conservation and development (Blaike et al., 1997, p. 222; Brown, 2002, p. 7). Hence, participatory allows communities to have greater control over their lives and resources and as a means of achieving improved social and economic objectives (Little, 1994, p. 350).

The same concern is also to discover if the Bung Jagoi Heritage CBC project is a success or a failure as self-organisation has been recognised by the EI of UNDP as key towards the victory of CBC (Shukla et al., 2010, p. 205). The Bung Jagoi Heritage CBC initiative is a complex system too which is parallel to Levin (1998; Gunderson and Holling, 2002 in Shukla et al., 2010, p. 206). The Bung Jagoi Heritage CBC initiative involves the local communities within the Jagoi area of various education level, interests, status, religion, political, and economic power. Besides that, it involves the local communities who are working with the public and private sectors where they have to divide their commitment in order to engage themselves in the CBC initiative. The community self-organisation criteria drawn from the analysis of the EI community-based projects managed by the UNDP in the equatorial region by Berkes et al. (2004) and Seixas et al. (2008), is utilised as the benchmark in this study to discover how the CBC project of Bung Jagoi Heritage originates, sustains, and develops until this present day. This subsequently will determine if the Bung Jagoi Heritage CBC project is a success or failure. The community self-organisation criteria are the trigger events and catalytic elements, funds or financial resources and other resources, capacity building and knowledge systems, leadership and key players.

The declaration of the forested ancestral land as communal forest, on the other hand, may create conflicts over access and appropriation of common-pool resources between land owners and resource users. Ostrom, Gardner, and Walker (1994) stated that common-pool resources is difficult by exclusion and generate limited quantities of resource units among the resource users. In the case of the ancestral land in Bung Jagoi before has been declared as communal forest, used to be in possession by right of an individual which the feeling of dissatisfaction will occur when the other BiJagoi villagers subtract more resources than the land owner itself. In respect to Bung Jagoi self-organised CBC initiative, a question regarding the system that is being utilises by the JADC to manage the communal forest is raised. How the adat helps in managing the access and forest resources in the Bung Jagoi Heritage communal forest? This study adopted Ostrom's (1990) design principles of managing common-pool resources that predicted as effective in self-organised resource management by the local communities. The reason Ostrom's (1990) design principles is adopted for the purpose of this study because some of the principles are present in the Bidayuh's adat institution which is part of the common property regime. Ostrom's (1990) design principles are (1) clear defined boundaries, (2) congruence, (3) collective choice arrangements, (4) monitoring users and resources, (5) graduated sanctions, (6) conflict resolution mechanisms, (7) 
minimal recognition of rights to organise, and (8) nested enterprises, in case of resources that are parts of larger systems.

In the first approach of $\mathrm{CBC}$, participation is fundamental in the conservation initiatives to ensure the success of the initiatives as the role of local participation is important in rural development programmes especially in the conservation programme (Little, 1994, p. 347). The Bung Jagoi Heritage $\mathrm{CBC}$ has this characteristic as it tries to conserve and develop the heritage simultaneously. As the $\mathrm{CBC}$ project require the local communities' participation, the participation of the local communities, however, are influenced by desire, motivation and decision to conserve natural resources where depends on the local communities' view towards the natural resources itself as "the idea that when biodiversity is more valuable to locals, they will do more to conserve it" (Western and Wright, 1994; Getz et al. 1999 as cited in Barrett, Brandon, Gibson, and Gjertsen, 2001, p. 497).

Moreover, according to Tole (2010, p. 1313), the decision for the individual to participate always include a kind of intuitive economic calculation of the costs and benefits of joining. In respect to Bung Jagoi Heritage CBC initiative, it is believed that the local communities do engage themselves in the $\mathrm{CBC}$ project. However, their participation in the conservation initiative is driven by certain motives. It is impossible for each one of the BiJagoi to be able to engage themselves in the $\mathrm{CBC}$ initiative because they have their own priorities in their daily life. (The committee members, on the other hand, some of them are living in the city to work) need to rephrase. Pretty, Guijt, Scoones, and Thompson (1995, p. 61) outlined seven types of participation which are useful in distinguishing the participation of local communities in a project.

\section{FACTORS CONTRIBUTING TO SUCCESSFUL IMPLEMENTATION OF CBC IN BUNG JAGOI}

There are four factors which contribute to successful implementation of self-organisation in CBC initiative as asserted by Berkes et al. (2004) and Shukla et al. (2010). The factors are adopted for the purpose of this study to unveil the origin of the project, how it sustains and develops. There

are four factors contributing to the implementation self-organisation in $\mathrm{CBC}$ initiative of Bung Jagoi Heritage will be discussed in the ensuing paragraph.

\section{Trigger Events and Catalytic Elements}

Based on the interview with the respondents, the Bung Jagoi Heritage's self-organised initiative was triggered by some outsiders' through their numerous visits to Bung Jagoi. Bung Jagoi has attracted a large number of outsiders which was believed to be highly educated and opulent. Their continuous visit occurred after most of the BiJagoi had moved down to the lowland areas, and they left the ancestral village abandoned with only one family still residing there. The outsiders' presence were detected by one of the Jagoi-Duyoh villagers who is now one of the committee membesr in JADC. However, none of the local communities in knew the outsiders' intention.

The scenario had raised the feeling of panic and suspicion which thereafter drove the local communities to protect and conserve their "ancestral property" especially the forested land and 
biodiversity from being destroyed, grabbed, and extracted by the government, outsiders, or any person that have the intention to gain personal benefit from the ancestral land. As one of the members of the JADC who are the participant of the Bung Jagoi Heritage CBC said, "We the Bidayuhs, own the place. So, we have to safeguard the place". The committee members interviewed were worried that their ancestral land will be grabbed by the government as the land in Bung Jagoi has no title, not being surveyed, and abandoned. Besides that, they feel worried that the timber found in Bung Jagoi will be extracted by the logging company.

Based on the interview with the committee members, the forested land in Bung Jagoi Heritage has abundant biodiversity that possesses economic values, for instance, tongkat ali (Eurycoma longifolia), an endangered long twisted roots herbal medicinal plant. Bhat and Karim (2010) in their study concerning ethnobotany and pharmacological importance of tongkat ali showed that it has the potential to be commercialise due to its marvels. Bung Jagoi Heritage also possesses several species of dipterocarp such as kabang (Shorea macrophylla), and tapang (Koompasia excelsa). Because of this, the committee members feel that it is essential to protect and preserve the biodiversity for current and future generation. One of the them articulated that “Oku raan suo koyuh de' kirin oku no'uh eh, onak sukun oku duoh nyaa joman de adin duoh itia ijok aruo dapod kirin koyuh inoh" which means "I would like all the trees that I ever see during my days can be seen by my children, my grandchildren, and the people of current and future generation".

The trigger event together with the commitment of the villagers has led a small number of local communities majorly from Jagoi-Duyoh village to start their own initiative to protect and preserve Bung Jagoi area while led them to established an informal CBO namely JADC to support and strengthen their effort. Between the year of 2012 and 2013, the JADC's various efforts have been made to safeguard the forested land which encompasses biodiversity and the ancestral village site of an area more than 400 hectares which declared as pulau tu'aan by the JADC with consent granted by the land owners. The committee members together with the villagers conducted a perimeter survey using Global Positioning System (GPS) to demarcate the forested land in Bung Jagoi Heritage. The main purpose is to gazette the forested land as Native Communal Reserve under Section 6 of the State Land Code through the Land and Survey Department which will be barring the state and other outsiders from appropriating village communally owned property.

The Bung Jagoi Heritage self-organisation trigger event has a slight similarity to the selforganisation cases analysed by Seixas et al. (2009) which is self-organisation that was triggered in interest to protect communal land resources. For the Bung Jagoi Heritage case, the mysterious visit and concerns to protect the ancestral land and its resources are the trigger event for the CBC initiative to emerge. These are the major factor that drove the conservation initiative. The committee members (local villagers) are the catalyst for the self-organisation as the initiative was derived from their own effort. The committee members have diverse background and knowledge. Another catalyst for the self-organisation of Bung Jagoi Heritage is the local and international agencies which both from governments and NGOs that provide donation and sources of knowledge. 


\section{Funding or Financial Resources and Other Resources}

The informal self-organised CBC in Bung Jagoi Heritage is a non-profit organisation. Based on the interview with the committee members, this self-organised CBC started with funds obtained from two international organisations namely RFN and DANIDA. The funds were obtained with the effort made by the participants of the CBC. They cooperated with the Krokong committee members who were also involving in a conservation project namely CBET. Apart from that, fund was also obtained from Shell Malaysia, The GEF under the SGP of UNDP, Ministry of Tourism and Heritage Sarawak, State and Federal Representatives, SBC, local leaders and committee members of the CBC initiative. In order to attain fund from the organisations and local leaders, the committee has to write a proposal regarding the activities that intend to be organised. The fund that has been approved by the organisations was released to the committee by stages. Furthermore, the committee was required to provide a financial report in relation to their expenditures on the project to the respective organisations. Funding from the organisations will cease upon failure to produce the required financial reports.. At present, this committee is no longer receiving fund from the UNDP and rely on the local leaders to source the necessary funds for this initiative. At the end of the year 2015, this self-organised CBC initiative was sponsored by the SBC with an amount of RM 1,700.00 to upgrade the existing infrastructures in the herbal garden and cultivate various types of herbs (the member of JADC, personal communication, December 25, 2015).

The funds were used to construct concrete steps equipped with wooden railings and wooden steps equipped with wooden railings toilets equipped with water supply build the new baruk (repairing and maintaining the old baruk, erected resting places equipped with benches for the visitors and signage boards In addition, equipments such as cameras, projector set and others were also purchased Monetary compensation were given to the local communities in exchange for the construction of the infrastructure. Whereas, those who were involved in Bung Jagoi CBC's activities were provided with meals for their services. Even though primarily funds are obtained from the benefactors,members of the JADC also used their own money to supplement the conservation initiatives. The JADC also attains small amount of financial resources from the parking fee paid by the visitors visit the heritage. The visitors have to pay an amount of RM 3.00 for their vehicles parked at the JADC Information Centre.

\section{Capacity Building and Knowledge System}

The BiJagoi especially the committee members are aware that the natural resources on their ancestral land are precious and needed to be conserved, therefore, capacity building is essential in this conservation initiative. Capacity building of Bung Jagoi Heritage follows a two-way process whereby both government or NGOs and communities interacted mutually and exchanged information from a variety of sources. Between the year 2008 and 2009, SBC and JOAS carried out environmental awareness programme at Bung Jagoi Heritage. The programmes were carried out by the two organisations separately in the same year. With the collaboration of UNIMAS and JADC, environmental awareness programmes were also being carried out for the secondary students who are residing within the Jagoi area. Training on documentation of medicinal plants was given by the SBC to the local communities so that the local communities are able to document and conserve the medicinal plant species. This was to assist the committee's six missions of setting-up herbal garden in Bung Jagoi Heritage such as; to make the area as a centre of herbaceous 
plant, to maintain the landscape by replanting plants that are able to be commercialised, to maintain the BiJagoi culture, to determine, record, and collect all the plants that has its usages in the daily life, to record and keep valuable plants, and, to maintain the Bidayuh's traditional knowledge in order to be inherit by the younger generations. Apart from that, for knowledge and educational purposes, the committee labelled the trees in Bung Jagoi Heritage with its scientific and local name.

In 2014, the Joint Transparency International Malaysia (TI-M) organised a workshop called 'Capacity Building Workshop on Forest Watch' initiative in Sarawak which was jointly organised with Forest Department Sarawak. One of the CBC committee members participated in the workshop. The workshop was aimed to enhance the knowledge of participants and the local communities who reside in the vicinity of forest on conservation and also secure the forest resources from being exploited by irresponsible parties and to ensure the sustainability of forests. In the same year, the SRB also held a campaign to clean the rivers and promote of a safe and healthy environment.

\section{Leadership and Key Players}

The self-organisation of CBC initiative of Bung Jagoi Heritage is led by an advisor. The advisor for the JADC is Datu Ik Pahon; the Permanent Secretary for Ministry of Tourism. Based on the interview, he is appointed to be the advisor of this committee due to his background that could sustain and develop the CBC initiative. In the case of Bung Jagoi Heritage, the advisor leadership can be categorised as bridge builders based on the leadership characteristic listed out by Timmer (2004 in Seixas et al., 2008, p. 115). The committee members are the key players in this CBC initiative because each of them holds different roles and responsibility in the organisation.

In 2007, after the establishment of the informal CBO, ketua kaum from each village and local communities from the Jagoi area; majorly from the Jagoi-Duyoh village became members of the JADC. In the committee, each of the members play a different role based on their background and interest. Some of them have connections with the local leaders, government agencies, and NGOs. Some of the committee members are working with those agencies and some of them are the pensioner formerly with the government agencies. All of the committee members participate voluntarily in the $\mathrm{CBC}$ initiative. The ketua kaum from each village, acts as a mediator to their respective villages. They are responsible for disseminating information to the villagers about the conservation activities.

\section{IMPACT OF ADAT ON ACCESS AND FOREST RESOURCE MANAGEMENT}

The BiJagoi common-property management is enabled through institutional evaluation. This is in relation to the second objective of this study which is to investigate the impact of customary law or adat on the access and forest resources management in Bung Jagoi Heritage. Ostrom's (1990) design principles for common properties institutions is applied to discuss the findings for the second objective of this study. The entire data are gathered from the SSIs. These data are analysed 
to determine the presence and functionality of the Bidayuh adat (including the BiJagoi adat) which may be affecting the access and forest resources management in Bung Jagoi Heritage. The results are presented based on the information obtained from the interviews that are related to access and forest resources management in Bung Jagoi Heritage only. The results present the boundaries, rules, monitoring and sanctions which possibly affect the access and resources management within the forested area.

\section{Users and Boundaries}

The significant impact of customary law or adat for the access and management of forest resources in Bung Jagoi Heritage is the provision of that clearly defined user. The right to the access and common-pool resources in the Bung Jagoi Heritage is strictly restricted to the BiJagoi only because it is their tolun tana' and tana' nyomba. Outsiders are definitely prohibited from entering and utilised forest resources in the Bung Jagoi Heritage. However, not all of the BiJagoi has the rights to access and to the common-pool resources in the communal forest. Based on the interview with the committee member, only the BiJagoi who are residing in Jagoi-Duyoh and Jagoi-Pinomu villages are allowed subtracting forest resources in the communal forest. Other BiJagoi are allowed access to the communal forest only as visitors and not as the resource users. Besides that, the rights to access and to the common-pool resources in the communal forest is in pursuant with their adat. It stated that a person who leaves the village will simply lose his land rights by failing to validate the land through cultivation. This is also similar to the BiJagoi adat. In the BiJagoi adat, cultivation rights to land which is validated by cultivation can be inherited downward only as far as the grandchildren. This means that an individual has no right to land cleared by his greatgrandfather except his grandfather or father has re-cleared and cultivated the same plot. Furthermore, the Adat Bidayuh Order, 1994 proclaims that a Bidayuh woman who is married to a non-Bidayuh man in a non Bidayuh custom, is supposed to relinquish all her rights under Chapter IV Section 181 of the said Order. Hence, she is not eligible to the common-pool resources in Bung Jagoi Heritage. Hence, gender bias in the adat is prevalent as woman is seen to have lower privileges towards the communally owned resources.

\section{Rules}

.There are numerous rules on forest resources management based on the adat of Native Customary Laws Ordinance and native custom. According to the BiJagoi adat, the collections of fruits in Bung Jagoi Heritage communal forest are only meant for farmers who planted them and the descendant of the farmers. However, based on the interview with the committee member, a modification has been made by the committee together with the land owners verbally. The other BiJagoi villagers of Jagoi-Duyoh and Jagoi-Pinomu villages are also allowed to harvests the fruits in the communal forest although they do not own the fruit trees. Through the alteration of the adat, it has serves as a resource-safety net as said by Fuys et. al. (2008) in Chapter Two. Based on the interview with the committee member, the farmer and the descendants as well as BiJagoi of JagoiDuyoh and Jagoi-Pinomu may sell their fruits collected from the communal forest either as the source of income or personal consumption. However, based on the FGD among the villagers and interview with the committee members, the villagers no longer collect fruits from Bung Jagoi as 
they have their own fruit trees in the lowland areas. Apart from that, selling of fruits is not their major source of income. Therefore, there are lots of unharvested fruits which can be seen in the Bung Jagoi Heritage during the fruit season, for instance, tibodak (Artocarpus heterophyllus). The possibility for occurrence conflict in the utilisation of forest resources to happen in the communal forest will be zero-conflict because the BiJagoi does not relies on the communal forest anymore.

Besides that, there is enforcement of strict rules towards the tapang tree (Koompassia excelsa) as stated in Chapter IV Section 46 (1) until Section 46 (3) of the Native Customary Laws Ordinance. The strict rules protect the owner of the tapang tree. The tapang tree is the tallest rainforest tree, particularly attractive to the wild honey bees to create their nests (de Jong, 2000). It is a protected plant in Sarawak (Sarawak Forestry Corporation [SFC] Ordinance, 2006). The BiJagoi addresses the tapang tree as tongon Do'oh (Do'oh tree). The inheritance of the tapang trees shares the same principles as the fruit trees tenure. The Native Customary Laws Ordinance prescribed strict rules on the use of tapang tree because it is a valuable source of honey and income for the Bidayuh (including BiJagoi). In the past, when a family or individual needs some cash, collecting honey from a tapang tree was a quick way to obtain cash. In Chapter IV under Section 46 (1), the act of harvesting wild honey without the permission from the owner of the tapang tree is not allowed whilst under Section 46 (2), a person will be levied adat fines of three pikul which is equal to RM 300.00 (one pikul equal to RM 100.00) for harvesting wild honey on another person's tapang tree without the permission of its owner. Besides that, all collection from the tapang tree be going to give back to the owner and if the collection has been sold or eaten its equivalent value in cash shall be paid to the owner.

It is a taboo to cut down a tapang tree as in Chapter IV Section 46 (3) stated that "Whoever fells another person's tapang tree shall provide takud ..." Takud covers the idea of providing settlement between individuals and covers the idea of appeasement, atonement or restoration of the physical and spiritual well-being of the community. According to Ibuh (2014, p. 137), there is taboo in Sarawak against cutting down the tapang tree. In relation to the statement, the cutting down of the tapang tree among the Bidayuh is also a taboo. Hence, takud in the aforesaid is referring to the second element of takud which covers the idea of appeasement, atonement or restoration of the physical and spiritual well-being of the community.

Another impact of customary law or adat for the access and management of forest resources in Bung Jagoi Heritage is a positive impact on the conservation of forest resources which the exploitation of the forest resources can be avoided. One factor is mentioned in this respects which is the origin of the rules, based on the (oral) traditions of adat and inherited from their ancestors. During the interview with a committee member, he mentioned that their ancestors created taboos (porih) by believing that if they destroy the forest, the spirit will punish them through a disaster that will affect their crops yield. On the other hand, a woman who participated in the FGD who still embraces the adat omba said that it is a taboo to destroy the forest because it is where the spirits called triu, komang, and iang reside. The komang was said to be the spirit of the departed heroes and has an appearance that could petrified people. The triu, komang, and iang are belief to reside in the old forest on the pinnacles of hills. This situation may relate to the restriction of cutting down timbers in the tu'aan raya apart from for conservation purposes. Based on the interview, the forest is the shelters for every species of flora and fauna which related to their traditional life. A type of bird which is known as kutieng was the BiJagoi omen bird because the 
calls from the bird will determine the activities of the BiJagoi such as farming, hunting, deciding spot to build a new house and travelling is favourable.

Even though the old belief seems not as convincing as in earlier times, it makes the Bung Jagoi Heritage as a sacred place by all the respondents interviewed. Hence, a signage was erected in the Bung Jagoi Heritage advised the visitors to abide by the local taboos and beliefs (Plate 1).

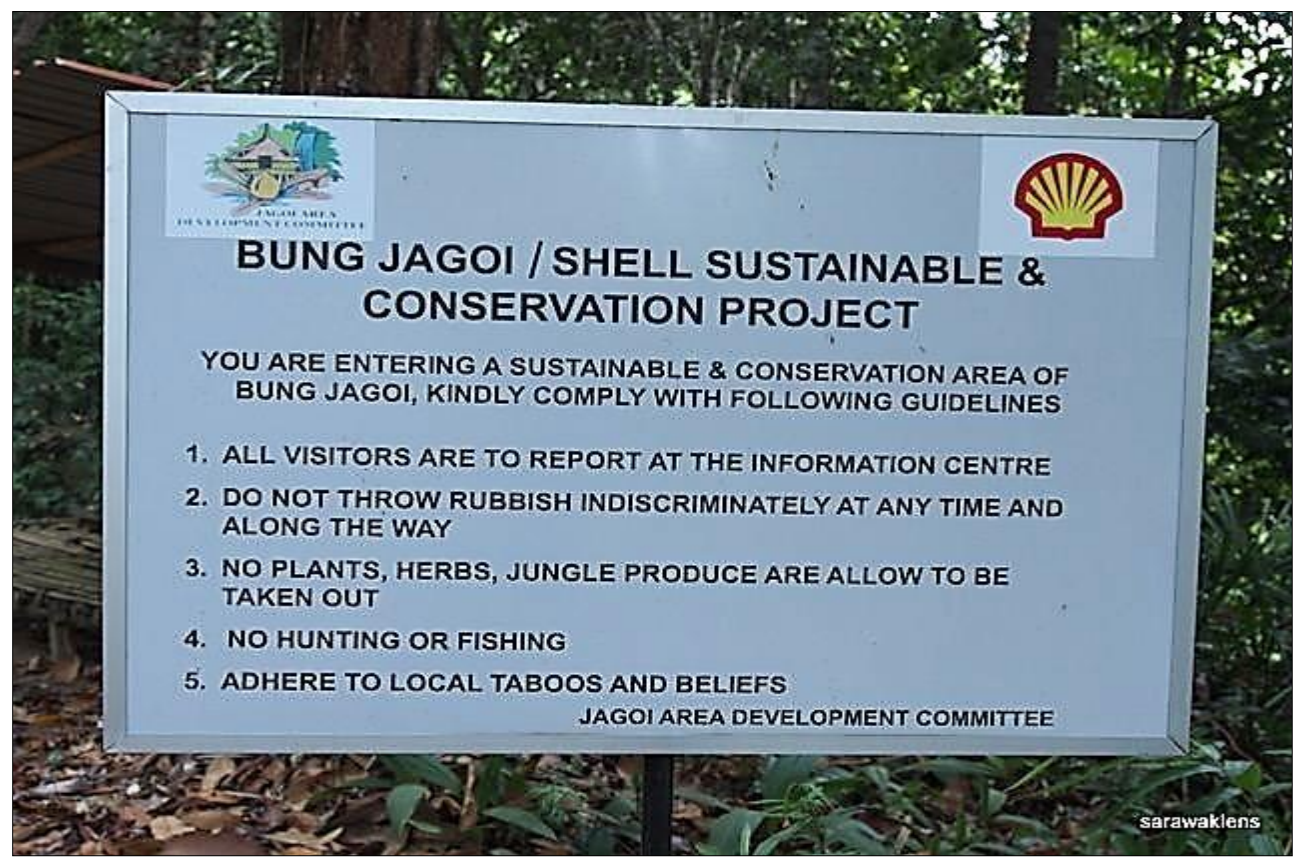

Plate 1 Guidelines to be abide by the visitors when entering the Bung Jagoi Heritage

The adat omba at the present time rarely practise in the Jagoi-Duyoh village because majority of the villagers embraces Christianity. Some of the villagers express their thought that it is tough to practise the adat omba especially involving the rituals activities as there are numerous of taboos to abide. If they failed to abide the taboos, something bad befalls upon them. However, the adat omba has the ability in managing the forest resources through porih created by the ancestors. The interviewed committee member claim that they mainly do that out of respect for the community which still embrace the old religion and believed in the porih, not because they believe in the vengeance of spirits.

\section{Monitoring and Sanctions}

Monitoring of resource use and the imposition of sanctions for violations should be carried out by either the members of the managing communal entity or by persons accountable to the members (Ostrom, 1990, p. 94). In addition, common-property regimes function best when sanctions are graduated and only repeat offenders are severely punished for non-compliance with rules and regulations (McKean, 2000; Ostrom, 1990). Appropriate monitoring of use and suitable sanctioning of violations are necessary to rule enforcement within a common-property institution. 
In the adat, punishment will be imposed towards individuals who commit violations of the village rules. In the case of Bung Jagoi Heritage, this punishment is implemented in managing the forest resources by the committee. There is a sanctioning mechanism for some inappropriate activities carried out in the communal forest. The committee imposed sanctions such as fines if anyone are caught breaking the rules such as unauthorised agricultural activities, hunting of wildlife, mining, cutting down trees and timbers, collecting forest produces such as plants and herbs, in the communal forest. The fine imposed depends on the committee members discretion which is applicable to both the outsiders and local communities. It is does not restricted to the adat fines such in the Adat Bidayuh Order, 1994 as adat are dynamic, fluid and change over time. Based on the interview with one of the committee members, he has caught one of the local visitors plucking a rare wild flower species. During that time, he guided the local visitor trekking in Bung Jagoi Heritage. He imposed fine towards the local visitor with an amount of RM 80.00 although he felt that the fine is not proportionate with the value of the wildflower. The amount of fine imposed is determined by the committee members as a means of punishment.

\section{PARTICIPATION IN BUNG JAGOI CBC}

Participation is part and parcel of CBC as one of its approaches is to integrate the goals of conservation and development. Nadasdy (2005, p. 217) and Souto et al. (2014, p. 1331) asserted that participation is conventional in the discourse of development and conservation and one of the methods in $\mathrm{CBC}$ when working with the local communities that aim to achieve conservation and development at the same time. Results present the level of participation among the villagers and the committee members.

Under the typology of participation, the level of participation among the committee members in the CBC can be characterised as 'self-mobilisation'. This is because they are to protecting, preserving, and managing the Bung Jagoi Heritage by mobilising their own resources and through external assistance. These are done through contacts with external institutions for financial support and technical advice needed, and at the same time retain control over how resources are used. The committee members have control over the resources in the communal forest which are under conservation through adat. There is no intervention from the external organisations in managing the communal forest in Bung Jagoi Heritage. In addition, the committee members conducted the perimeter survey in the effort to safeguard the forested land which encompasses biodiversity and the ancestral village on top of the Bung Jagoi by themselves. The committee members participation is similar to literature cited from Western et al. (1994) in Barrett et al. (2001, p. 497) stated that "the idea that when biodiversity is more valuable to locals, they will do more to conserve it".

\section{CONCLUSIONS}

This article has discussed a self-organisation activities in CBC initiative of Bung Jagoi Heritage. The factors which lead to the success are contributed and influenced by of trigger event and catalytic elements, funds or financial resources, capacity building and knowledge system, 
leadership and key players. The implementation of self-organisation in CBC initiative of Bung Jagoi Heritage is triggered by the idea from the outsiders' mysterious visit, and concerns on protecting the ancestral land and its resources. The catalyst for the implementation of the selforganisation is the committee members themselves because the initiative derived from their efforts. Other catalysts are the local and international agencies which both from governments and NGOs that provide donation and sources of knowledge. The conservation project sustains and develops through the fund or financial resources acquire from the committee members and external organisations both from local and international government agencies. Besides that, capacity building activities and strong leadership sustain and develops the heritage until present day. This self-organisation is also found to be focusing more on the conservation of natural resources.

In relation to the customary arrangements of the second approach in $\mathrm{CBC}$, this study shows that the adat gives positive impacts to both the BiJagoi and conservation project where it is able to avoid the dispute over the access and forest resources. However, the adat disadvantages the women who are married to a non-Bidayuh man when the marriage is not in accordance with the Bidayuh custom. The level of participation of the BiJagoi in the conservation and development are divided into two phases. The level of participation among the villagers are predominantly focused on material incentives for their own financial benefits while the level of participation among the committee members is self-mobilisation as the conservation is managed and control by themselves.

\section{References}

Adger, W. N., Benjamisen, T. A., Brown, K., \& Svarstad, H. (2001). Advancing a political ecology of global environmental discourses. Development and Change, 32 (4), 681-715.

Agrawal, A., \& Gibson, C. C. (1999). Enchantment and disenchantment: the role of community in natural resource conservation. World development, 27 (4), 629-649.

Agrawal, A., \& Gibson, C. C. (2001). Communities and the environment: Ethnicity, gender, and the state in community-based conservation. United States of America: Rutgers University Press.

Alcorn, J. B. (1996). Forest use and ownership: Patterns, issues, and recommendations. In Schelhas, J., and Greenburg, R. (Eds.), Forest Patches in Tropical Landscapes (pp. 233257). Washington, D. C.: Island.

Alcorn, J. B. (2000). An introduction to the linkages between ecological resilience and governance. In Alcorn, J. B. \& Royo, A. G. (Eds.), Indigenous social movements and ecological resilience (pp. 1-16). Washington, D. C.: Biodiversity Support Programme.

Alcorn, J. B. (2005). Dances around the fire: conservation organizations and communitybased natural resource management. In Brosius, J. P., Tsing, A. $\quad$ L., \& Zerner, C. (Eds.), 
Communities and conservation: Histories, and politics of community-based natural resource management (pp. 37-68).

United States of America: AltaMira Press.

Appell, G. N. (1971, June). System of land tenure in Borneo. A problem in ecological determinism. Borneo Research Bulletin, 3 (1), 1-42.

Appell, G. N. (1991, September). Resource management regimes among the swidden agriculturalists of Borneo: does the concept of common property adequately map indigenous systems of ownership. In Paper to Common Property Conference, Winnipeg.

Appell, G. N. (1997). The history of research on traditional land tenure and tree ownership in Borneo. Borneo Research Bulletin, (28), 82-97.

Azima, A. M., Lyndon, N. \& Akmal, M. S. (2015). Understanding of the meaning of Native Customary Land (NCL) boundaries and ownership by the Bidayuh community in Sarawak, Malaysia. Mediterranean Journal of Social Sciences.

6 (5), 342-348. doi: 10.5901/mjss.2015.v6n5s1p342.

Banana, A. Y. \& Gombya-Ssembajjwe, W. (2000). Successful forest management: The importance of security of tenure and rule enforcement in Ugandan forests.

In Gibson, C. C., McKean, M. A., Ostrom, E. (Eds.), People and forest: Communities, institutions, and governance (pp. 87-98). Massachusetts: The MIT

Press.

Barrett, C. B., Brandon, K., Gibson, C., \& Gjertsen, H. (2001). Conserving tropical biodiversity amid weak institutions. BioScience, 51 (6), 497-502. doi: $\quad$ 10.1641/00063568(2001)051[0497:ctbawi]2.0.co;2

Berkes, F., \& Seixas, C. (2004). Lessons from community self-organization and cross- scale linkages in four Equator Initiative projects. Equator Initiative Synthesis Report. Winnipeg: Natural Resources Institute, University of Manitoba. Berkes, F., \& Davidson-Hunt, I. J. (2007). Communities and social enterprises in the age of globalization. Journal of enterprising communities: people and places in the global economy. 1 (3), 209-221. 
Blaikie, P., Brown, K., Stocking, M., Tang, L., Dixon, P., \& Sillitoe, P. (1997). Knowledge in action: Local knowledge as a development resource and barriers to its incorporation in natural resource research and development. Agricultural systems, 55 (2), 217-237.

Boudreaux, K. (2008). A new call of the wild: Community-based natural resource management in Namibia. Georgetown International Environmental Law Review, 20 (2), 297- 335 .

Brown, K. (2003). Three challenges for a real people-centred conservation. Global Ecology \& Biogeography, 12 (2), 89-96.

Bulan, R. (2006). Native Customary Land: The trust as a device for land development in Sarawak. In Cooke, F. M. (Eds.) Asia-Pacific Environment Monograph 1. State, communities and forests in contemporary Borneo (pp.45-64). Australia: ANU Press.

Campbell, L. M., \& Vainio-Mattila, A. (2003). Participatory development and communitybased conservation: Opportunities missed for lessons learned?

Human Ecology, 31 (3), 417-437.

Chambers, R. (1994). The origins and practice of participatory rural appraisal. World Development, 22 (7), 953-969.

Chang, P. H. (2002). History of the Bidayuh in Kuching Division. Malaysia: Sarawak Press Sdn. Bhd.

Chatty, D. \& Colchester, M. (2002). Conservation and mobile indigenous peoples. In Chatty, D. \& Colchester, M. (Eds.), Conservation and mobile indigenous peoples: Displacement, forced settlement, and sustainable development (pp. 77- 96). New York: Berghahn Books.

Chilvers, J. (2009). Deliberative and participatory approaches in environmental geography. In Castree, N., Demeritt, D., Liverman, D. \& Rhoads, B. (Eds.), A companion to environmental geography (pp. 400-418). United Kingdom: Wiley- Blackwell.

Church, R. M. (2001). The effective use of secondary data. Learning and Motivation, (33), $32-45$.

Cornwall, A. (2008). "Unpacking Participation": Models, meanings and practices." Community Development Journal, 43 (3), pp. 269-283. 
De Jong, W. (2000). Micro-differences in local resource management: The case of honey in West Kalimantan, Indonesia. Human Ecology, 28 (4), pp. 631-639.

Dealwis, C. \& David, M. K. (2007). Shy speakers: Hearing their voices. Migracijske $i \quad$ etničke teme, 23 (1-2), 51-64.

Dove, M., Sajise, P. E., \& Doolittle, A. A. (2005). Conserving nature in culture. Case studies from Southeast Asia. In Dove, M., Sajise, P. E., \& Doolittle, A.A., (Eds.), Introduction: The problem of conserving nature in cultural landscapes. Monograph 54. Connecticut: Yale University Southeast Asia Studies.

Dixon, G. (April, 1974). Dayak land tenure: An alternative to ecological determinism. Borneo Research Bulletin, 6 (1), 1-28.

Eghenter, C. (2000). What is tana ulen good for? Considerations on indigenous forest management, conservation, and research in the interior of Indonesian Borneo. Human Ecology, 28 (3), 331-357. doi:10.1023/A:1007068113933

Feeny, D., Berkes, F., McCay, B. J. \& Acheson, J. M. (1990). 'The tragedy of the commons: twenty-two years later'. Human Ecology, 18 (1), 1-19.

Fernandes, D. (2004). Community-based Araipama conservation in the North Rupuni, Guyana, Equator Initiative technical report. Winnipeg: Natural Resources Institute, University of Manitoba.

Gibson, C. C., McKean, M. A., \& Ostrom, E. (2000). People and forests: Communities, institutions, and governance. The MIT Press.

Hackel, J. D. (1999). Community conservation and the future of Africa's wildlife. Conservation Biology, 13 (4), 726-734.

Hox, J. J. \& Boije, H. R. (2005). Data collection, primary vs secondary. Encyclopedia of Social Measurement, (1), 593-5999.

Hulme, D. \& Murphree, M. (1999). Communities, Wildlife and 'new conservation' in Africa. Journal of International Development, 11 (2), 277-286. 
Horowitz, L. S. (1998). Integrating indigenous resource management with wildlife conservation: A case study of Batang Ai National Park, Sarawak, Malaysia.

Ecology, 26 (3), 371-403.

Ibuh, R. (2014). The Kayans. A journey through their rich cultural heritage and legacy.

Singapore: Partridge.

Intan, J. (2014). Strategi kelangsungan hidup dan pembangunan mampan dalam kalangan komuniti sempadan: Kajian perbandingan di Lubok Antu, Tebedu, dan Serikin. (Unpublished master's thesis). Universiti Malaysia Sarawak, Kota Samarahan.

Järvilehto, L. (2005). Men and women of the forest. Livelihood strategies and conservation from a gender perspective in Ranomafana National Park, Madagascar. (Master's Thesis). University of Helsinki, Finland.

Jeffreys, W. J. (2010). Chapter 9. Compensation crisis, adat law, and unresolved land issues in Sarawak, Malaysia. In Eguavoen, I. \& Laube, W (Eds), Negotiating local governance: Natural resources management at the interface communities and state (pp. 211-235). Germany: LIT VERLAG.

Kumar, C. (2007). Whither 'community-based' conservation? Economic and Political Weekly. 41 (52), 5513-5320.

Khwaja, A. I. (2004). Is increasing community participation always a good thing? Journal of the European Economic Association, 2 (2-3), 427-436.

Laws, S. (2003). Research for development. New Delhi: Vistaar Publications.

Levin, S. A. (1999). Fragile dominion. Complexity and the commons. Cambridge: Perseus Publishing.

Majlis Adat Istiadat. (1994). Adat Bidayuh. Kuching: Printing Office. 
Maurice, S. (2006). Self-organization and cross-scale interactions in integrated development and conservation projects: A comparative study of Honey Care Africa's beekeeping projects in Kakamega District and Kwale District, Kenya. (Master theses). University of Manitoba, Winnipeg.

McCarthy, J. F. (2005). Between adat and state: Institutional arrangements on sumatra's frontier. Human Ecology. 33 (1), 57-82.

McKean, M. A. (2000). Common property: What is it, what is it good for, and what makes it work? In Gibson, C. C., McKean, M. A., Ostrom, E. (Eds.), People and forest: Communities, institutions, and governance (pp. 27-55). Massachusetts: The MIT Press.

Meine, C. (2009). This place in time. In Knight, R. L. \& White, C. (Eds.), Conservation for a new generation: Redefining natural resources management (pp.11-30). $\quad$ Washington, D. C.: Island Press.

Mikkelsen, B. (2005). Methods for development work and research: a new guide for practitioners: Second edition. New Delhi: Sage Publications.

Nelson, J., Muhammed, N., \& Rashid, R. A. (2015). An empirical study on compatibility of Sarawak Forest Ordinance and Bidayuh Native Customary Laws in forest management. Small-scale Forestry, 1-14. doi: 10.1007/s11842- 015-9313-y

Olsson P., C. Folke \& F. Berkes (2004). Adaptive co-management for building resilience in social-ecological systems. Environmental Management. (34), 75-90.

Ooi, K. G. (2010). The A to Z of Malaysia. America: Scarecrow Press, Inc.

Ostrom, E. (1990). Governing the commons: The evolution of institution for collective action. United Kingdom: Cambridge University Press.

Ostrom, E., Gardner, R., \& Walker, J. (1994). Rules, games, and common-pool resources. United States of America: The University of Michigan Press. 
Ostrom, E. (2000). "Private and common property rights”, Workshop in Political and Policy Analysis, and Centre for the Study of Institutions, Population, and Environmental Change, (pp. 332-379). Indiana University.

Ostrom, E., \& Hess, C. (2007). Understanding knowledge as a commons .From Theory to Practice. England: The MIT Press.

Pretty, J. N., Guijt, I., Thompson, J., \& Scoones, I. (1995). Participatory learning and action: A trainer's guide. London: International Institute for Environment and Development.

Malone, P. (2014). The peaceful people. The Penan and their fight for the forest. Selangor, Malaysia: Strategic Information and Research Development Centre.

Qazi, S. A., \& Qazi, N. S. (2008). Natural resources conservation and environment management. New Delhi: A P H Publishing Corporation.

Rahnema, M. (2005). Participation. In W. Sachs (Eds.), The development dictionary: A guide to knowledge as power. Second Edition (pp. 116-131). London: Zed Books.

Ruiz-Mallén, I., Schunko, C., Corbera, E., Rös, M., \& Reyes-García, V. (2015). Meanings, drivers, and motivations for community-based conservation in Latin America. Ecology and Society, 20 (3), 33. doi:10.5751/ES-07733-200333

Russell, E. (2010). Afterword: Militarized landscapes. In Pearson, C., Coates, P., \& Cole, T. (Eds.), Militarized Landscapes: from Gettysburg to Salisbury Plain (pp. 229248). New York: Continuum.

Samuel, P. H. (1999). Conservation and the Gospel of Efficiency: The Progressive Conservation 1890-1920. United States of America: University of Pittsburgh Press.

Sayok, A. K., Noweg, G. T., \& Pahon, W.I. (2014). Jagoi Heritage. A peek at the ancestral sites, forest and community. Kota Samarahan: The Institute of Biodiversity and Environmental Conservation. 
Seixas, C. S. \& Davy, B. (2008). Self-organization in integrated conservation and development initiatives. International Journal of the Commons, 2 (1), 99-

125.

Seixas, C. S., Davy, B., Leppan, W. (2009). Community-based conservation and development: Lessons learned from the 2004 Equator Prize. Canadian Journal of Development Studies / Revue canadienne d'études du développement, (28), 3-4, 523-552. doi: $10.1080 / 02255189.2009 .9669228$

Shukla, S. R. \& Sinclair, A. J. (2010). Strategies for self-organization: Learning from a village-level community-based conservation initiative in India. Human ecology, 38 (2), 205-215.

Silva, J. A. \& Mosimane, A. (2014). "How could I live here and not be a member?" Economic versus social drivers of participation in Namibian conservation programs. Human Ecology, (42), 183-197. doi: 10.1007/s10745-014-9645-9

Souto,T., Deichmann, J. L., Núñez, C., \& Alonso, A. (2014). Classifying conservation targets based on the origin of motivation: implications over the success of community-based conservation projects. Biodiversity and conservation, 23 (5),

1331-1337. doi: 10.1007/s10531-014-0659-9

Tan, C. B. (1997). Indigenous people, the state and ethnogenesis: A study of the communal associations of the "Dayak" communities in Sarawak, Malaysia. Journal of Southeast Asian Studies. 28 (2), 263-284.

Tang, C.-P., \& Tang, S.-Y. (2010). Institutional adaptation and community-based conservation of natural resources: The cases of the Tao and Atayal in Taiwan. Human Ecology, (38), 101111.

Tucker, C. M. (1998). Evaluating a common property institution: design principles and forest management in a Honduran community. Publisher not identified.

Wells, M. P., and Brandon, K. E. (1993). The principles and practice of buffer zones and local participation in biodiversity conservation. Ambio 22 (2-3), 57-162.

Wenger, E. (2000). Communities of practice and social learning systems. 
Organization, 7 (2), 225-246. 